\title{
ESTIMATION OF OPTIMUM TIME FOR INSEMINATION OF GILTS AND EWES BY DOUBLE-MATING AT CERTAIN TIMES RELATIVE TO OVULATION
}

\author{
P. DZIUK \\ Department of Animal Science, University of Illinois, \\ Urbana, Illinois 61801, U.S.A. \\ (Received 20th Fune 1969)
}

\begin{abstract}
Summary. Forty litters of pigs were produced following the doublemating of gilts at a 6 -hr interval by boars whose offspring could be distinguished from each other. The time of insemination relative to ovulation was designated precisely $\left( \pm \frac{1}{2} \mathrm{hr}\right.$ ) for each gilt. For analysis, gilts were put into four groups with reference to the time the first boar was used; 30 to 24,20 to 16,14 to 12 and 10 to $6 \mathrm{hr}$ before ovulation. The first boar sired $33 \%$ and $30 \%$ of the offspring when he was used at the longest intervals and $78 \%$ and $71 \%$ of the offspring at the two shortest intervals.

Matings of 147 ewes took place first at 23,19, 15, 11 or $7 \mathrm{hr}$ before ovulation and again $4 \mathrm{hr}$ later. The conception rates were $39 \%, 32 \%$, $81 \%, 43 \%$ and $32 \%$, respectively. The proportion of offspring from the first ram was $51 \%$ from the matings at the two longest intervals and $67 \%$ from the three shortest. The optimum time for insemination appeared to be about $12 \mathrm{hr}$ before ovulation in both species.
\end{abstract}

\section{INTRODUCTION}

There is probably a time for gilts and ewes in oestrus when an insemination is more apt to lead to pregnancy than inseminations either earlier or later (Niwa, 1961; Willemse, 1966; Inskeep \& Cooke, 1968). This optimum time can be assumed to be related to some symptom of oestrus or to the time of ovulation. The time of ovulation was chosen in the present study because it can be fixed objectively and experiments were designed to determine the optimum time for insemination relative to the time of ovulation. It was reasoned that semen inseminated at the time closest to the optimum would account for a greater proportion of offspring than semen used at a less favourable time. The following report is of experiments in gilts and ewes double-mated at certain times relative to a controlled time of ovulation.

Swine

\section{MATERIALS AND METHODS}

Forty litters from Duroc (Red, R) gilts were examined following mating (seven gilts) or artificial insemination (thirty-three gilts) to Duroc and York- 
shire (White, W) boars with a 6 -hr interval between boars. The first boar was used 30 to 24,20 to 16,14 to 12 or 10 to $6 \mathrm{hr}$ before ovulation. The time of insemination relative to ovulation was designated precisely $\left( \pm \frac{1}{2} \mathrm{hr}\right)$ but for the sake of convenience in analysing and presenting data, gilts were grouped arbitrarily as stated. One semen sample was divided and used for artificial insemination of seven to ten gilts whose time to ovulation varied as described. The gilts mated naturally were each served once by each boar. The $\mathrm{W}$ boars were used first on twenty occasions and the $\mathrm{R}$ boars were also used first on twenty occasions.

The time of ovulation was controlled in the artificially inseminated gilts by oral administration of $150 \mathrm{mg}$ of ICI 33828 in $2.2 \mathrm{~kg}$ of a dry ground meal fed once daily for 18 days. This was followed by the subcutaneous (s.c.) injection of 500 to 750 i.u. of pregnant mares serum gonadotrophin (PMSG) $24 \mathrm{hr}$ after the last feeding. Ovulation time was controlled by the intramuscular (i.m.) injection of 500 i.u. of human chorionic gonadotrophin (HCG) $96 \mathrm{hr}$ after PMSG. Ovulation was controlled in the naturally mated gilts by injection of 500 i.u. HGG during pro-oestrus. Ovulation was presumed to occur $40 \mathrm{hr}$ after HGG (Dziuk \& Baker, 1962). Gilts were assigned to a particular insemination time before treatment and all were inseminated.

The colour of the offspring was determined at 85 to 90 days of gestation or at birth.

\section{Sheep}

During the breeding seasons of 1964 to 1968,147 white-faced (W) ewes were double-mated by two natural services each by black-faced (B) and whitefaced rams. The first ram was used 23, 19, 15, 11 or $7 \mathrm{hr}$ before ovulation and the second ram $4 \mathrm{hr}$ later. The ewes were treated in groups of ten with the $B$ or $\mathrm{W}$ ram first an equal number of times. The time of ovulation was controlled in some groups by fourteen daily feedings of a progestagen followed by an i.m. injection of 250 i.u. of HCG 48 or $50 \mathrm{hr}$ after the last feeding (Dziuk, 1965a). Ovulation was also controlled by the s.c. implantation of silicone rubber impregnated with a progestagen or progesterone followed by HCG $28 \mathrm{hr}$ after removal (Dziuk, Cook, Niswender, Kaltenbach \& Doane, 1968). Ovulation was presumed to occur $25 \mathrm{hr}$ after HCG (Dziuk, 1965a). Ewes were assigned to mating times before treatment began and mating was forcibly attempted when ewes were not in heat at the appointed time. The colour of lambs was determined at 130 to 140 days of gestation or after lambing.

One group of twenty-nine ewes had a progesterone implant for 14 days during January, near the end of the breeding season, and HCG was given $28 \mathrm{hr}$ after removal of the implant. The ewes were exposed to a group of eight fertile rams for $2 \mathrm{hr}$ between 10 and $12 \mathrm{hr}$ before ovulation. They were examined for pregnancy at 35 days of gestation by laparotomy. The data for all experiments were subjected to Chi square analysis.

\section{Swine}

\section{RESULTS}

The first male sired a smaller proportion of the offspring when used from 
30 to $16 \mathrm{hr}$ before ovulation, but sired a greater proportion $(P<0.01)$ when used from 14 to $6 \mathrm{hr}$ before ovulation (Table 1 ). The switch from predominance of the second male to that of the first male occurred quite abruptly over an 8-hr period between 20 and $12 \mathrm{hr}$ before ovulation. A boar used either first or second at 10 to $14 \mathrm{hr}$ before ovulation had two- to three-times the likelihood of siring any one offspring than a competing boar used either $6 \mathrm{hr}$ earlier or later.

TABLE 1

FERTILITY OF GILTS AND PARENTAGE OF PIGS FOLLOWING DOUBLE-MATING AT A 6-HR INTERVAL

\begin{tabular}{|c|c|c|c|c|c|c|c|}
\hline \multirow[b]{2}{*}{$\begin{array}{l}\text { Interval from } \\
\text { first boar to } \\
\text { ovulation } \\
(h r)\end{array}$} & \multicolumn{3}{|c|}{ Gilts } & \multirow[b]{2}{*}{$\begin{array}{l}\text { Litter } \\
\text { size } \\
\text { (no.) }\end{array}$} & \multicolumn{3}{|c|}{ Offspring } \\
\hline & $\begin{array}{l}\text { Total } \\
(\text { no. })\end{array}$ & $\begin{array}{r}F \\
(n o .)\end{array}$ & $\stackrel{a n t}{(\%)}$ & & $\begin{array}{l}\text { From } \\
1 \text { stô } \\
\text { (no.) }\end{array}$ & $\begin{array}{l}\text { From } \\
\text { 2ndô } \\
\text { (no.) }\end{array}$ & $\begin{array}{l}\text { From } \\
1 \text { sto } \\
(\%)\end{array}$ \\
\hline $\begin{array}{l}30 \text { to } 24 \\
20 \text { to } 16 \\
14 \text { to } 12 \\
10 \text { to } 6 \\
\text { Combined }\end{array}$ & $\begin{array}{r}18 \\
13 \\
9 \\
11 \\
51\end{array}$ & $\begin{array}{r}12 \\
9 \\
9 \\
10 \\
40\end{array}$ & $\begin{array}{r}67 \\
69 \\
100 \\
91 \\
78\end{array}$ & $\begin{array}{l}7 \cdot 3 \\
8 \cdot 1 \\
8 \cdot 2 \\
9 \cdot 3 \\
8 \cdot 2\end{array}$ & $\begin{array}{r}29 \\
22 \\
58 \\
66 \\
175\end{array}$ & $\begin{array}{r}59 \\
51 \\
16 \\
27 \\
153\end{array}$ & $\begin{array}{l}33 \\
30 \\
78^{* *} \\
71^{* *} \\
52\end{array}$ \\
\hline
\end{tabular}

** Significantly higher than from second male $(P<0.01)$.

TABLE 2

FERTILITY OF EWES AND PARENTAGE OF LAMBS FOLLOWING DOUBLE-MATING AT A 4-HR INTERVAL

\begin{tabular}{|c|c|c|c|c|c|c|c|c|c|c|}
\hline \multirow{2}{*}{$\begin{array}{c}\text { Interval from } \\
\text { mating first } \\
\text { ram to ovulation } \\
(\mathrm{hr})\end{array}$} & \multicolumn{5}{|c|}{ Ewes } & \multicolumn{5}{|c|}{ Offspring } \\
\hline & $\begin{array}{l}\text { Total } \\
\text { (no.) }\end{array}$ & $\begin{array}{c}\text { Mated } \\
(\text { no. })\end{array}$ & $\begin{array}{c}\text { In } \\
\text { heat } \\
\text { (no.) }\end{array}$ & $\underset{\text { (no.) }}{\operatorname{Lan}}$ & $\begin{array}{l}\text { nbed } \\
(\%) \dagger\end{array}$ & $\begin{array}{c}B^{*} \\
(n o .)\end{array}$ & $\begin{array}{c}W \\
(n o .)\end{array}$ & $\begin{array}{l}\text { From } \\
1 \text { sto } \\
\text { (no.) }\end{array}$ & $\begin{array}{l}\text { From } \\
\text { 2ndठే } \\
\text { (no.) }\end{array}$ & $\begin{array}{l}\text { From } \\
1 \text { sto } \\
(\%)\end{array}$ \\
\hline $\begin{array}{r}23 \\
19 \\
15 \\
11 \\
7 \\
\text { Combined }\end{array}$ & $\begin{array}{r}28 \\
33 \\
25 \\
33 \\
28 \\
147\end{array}$ & $\begin{array}{r}23 \\
28 \\
21 \\
21 \\
25 \\
118\end{array}$ & $\begin{array}{l}16 \\
15 \\
18 \\
19 \\
16 \\
84\end{array}$ & $\begin{array}{r}9 \\
9 \\
17 \\
9 \\
8 \\
52\end{array}$ & \begin{tabular}{l|}
39 \\
32 \\
$81 * *$ \\
43 \\
32 \\
44
\end{tabular} & $\begin{array}{r}10 \\
5 \\
10 \\
6 \\
4 \\
35\end{array}$ & $\begin{array}{r}5 \\
3 \\
5 \\
4 \\
7 \\
27\end{array}$ & $\begin{array}{r}8 \\
4 \\
9 \\
8 \\
7 \\
36\end{array}$ & $\begin{array}{r}7 \\
4 \\
6 \\
2 \\
4 \\
23\end{array}$ & $\begin{array}{l}53 \\
50 \\
60 \\
80 \\
64 \\
61\end{array}$ \\
\hline
\end{tabular}

When $\mathrm{W}$ boars were used first, eighty-three offspring were $\mathrm{W}$ and seventy-five were $R$; when $R$ boars were first, seventy-eight offspring were $W$ and ninetythree were $\mathrm{R}$. In all, there were $161 \mathrm{~W}$ offspring and $168 \mathrm{R}$. The offspring in nine litters were all $R$, in twelve litters they were all $W$ and in nineteen litters they were mixed. Each boar sired some offspring and there was no indication that any one boar had an inherent advantage over any other.

\section{Sheep}

There was no difference between the first and the second ram in the proportion of offspring they sired at any one of the times before ovulation (Table 2). 
When data are combined for ewes mated first 15,11 and $7 \mathrm{hr}$ before ovulation, the first ram sired twenty-four lambs and the second ram twelve lambs. These differences between combined data are statistically significant $(P<0 \cdot 05)$. The proportion of mated ewes that lambed was higher $(P<0.01)$ for the ewes mated first $15 \mathrm{hr}$ before ovulation than for other ewes.

Some ewes died or aborted lambs whose paternity could not be established, which accounts for those instances where there are more ewes pregnant than lambs classified.

Of the twenty-nine ewes exposed to a group of rams for the period 10 to $12 \mathrm{hr}$ before ovulation, twenty-five mated and seventeen $(68 \%$ of those mated) were pregnant 35 days later.

Swine

\section{DISCUSSION}

The optimum time for insemination appears to be $12 \mathrm{hr}$ before ovulation. Deviations of $6 \mathrm{hr}$ from this time may have little apparent effect on fertility in

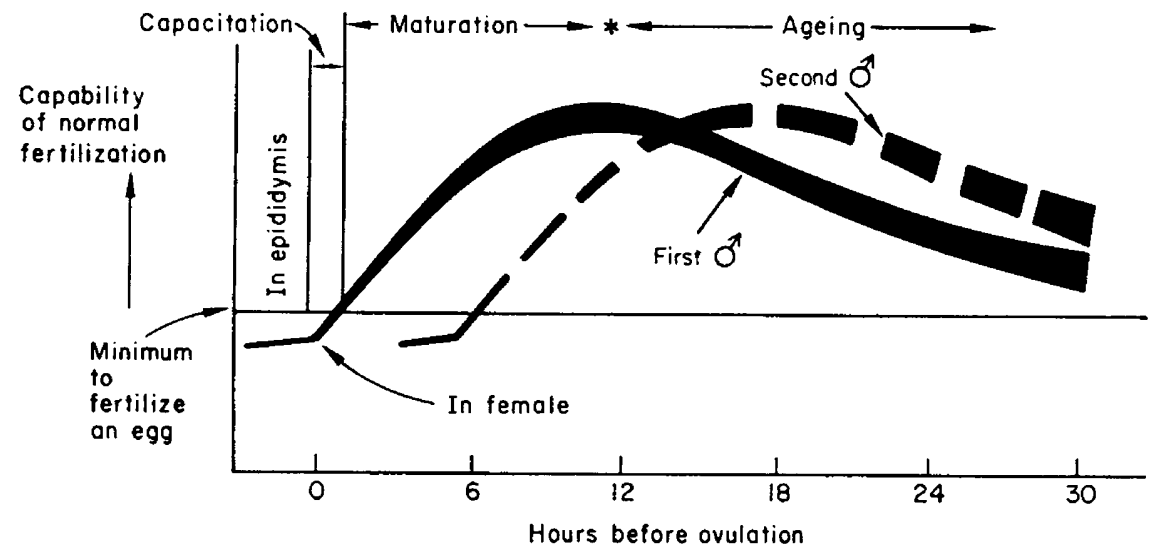

Text-Fig. 1. Hypothesis for the advantage one male has over the other following double-mating

small numbers of inseminations in a non-competitive situation. Inseminations at 18 or $6 \mathrm{hr}$ before ovulation did not compete successfully with those at $12 \mathrm{hr}$ before ovulation. This effect of the time of insemination is in accord with the observations of Niwa (1961) and Willemse (1966). Willemse obtained optimal results for fertility of ova, percentage of gilts pregnant and litter size when inseminations were carried out about $11 \mathrm{hr}$ before the end of the period when the gilt would stand for the inseminator, which is $33 \mathrm{hr}$ after the onset of this period. It might be presumed on the basis of other evidence that ovulation occurred $11 \mathrm{hr}$ after insemination, near the end of the period when the gilt would stand for the inseminator (Day, 1962).

Whether conception rate and litter size would be enhanced by inseminating at $12 \mathrm{hr}$ before ovulation as compared to other times could be determined by the insemination of a large number of gilts at a fixed time (Polge, Day \& Groves, 1968). 
McKenzie (1932) and Haring (1937) found that the first of two boars sired most of the one-sire litters and most of the offspring when gilts were doublemated during oestrus. They had no accurate estimate of time of ovulation but the present results suggest that, in their experiments, the second boar was used less than $12 \mathrm{hr}$ from ovulation.

When the data of two separate experiments on double-mating in rabbits (Dziuk, 1965b; Miller, Roche \& Dziuk, 1969) are combined, the first male sired $18 \%, 39 \%, 54 \%, 83 \%$ and $84 \%$ of the offspring when used $19,16,13,10$ or $<10 \mathrm{hr}$ before ovulation, respectively. It appears that not only do the pig and rabbit respond similarly but that the optimum interval between insemination and ovulation is nearly the same.

A hypothesis to explain the several previous observations is proposed in Text-fig. 1. Spermatozoa do not achieve capacitation or reach the minimum level of maturation necessary to fertilize an egg until some time after deposition in the female tract in some species, notably the rabbit. Once spermatozoa have achieved a minimum level, found to be as short as $3 \mathrm{hr}$ in the gilt (Hunter \& Dziuk, 1967), they become increasingly able to fertilize eggs up to about $12 \mathrm{hr}$ after deposition but from this time, fertilizing ability decreases (Roche, Dziuk \& Lodge, 1968). During this time of decreasing fertilizing ability, other spermatozoa nearer the peak of maturity may compete successfully in fertilizing eggs.

The population of spermatozoa in any one ejaculate is undoubtedly heterogeneous, a fact which may account for lack of complete dominance of a particular ejaculate. The innate advantage spermatozoa of certain males have over spermatozoa of others (Saison \& Moxley, 1966; Sumption, 1961) was not seen in the present experiment.

\section{Sheep}

The effect of time of mating on the parentage of offspring was not as clear in the ewe as in the gilt but the interval from mating to ovulation did have a significant effect on the proportion of ewes that conceived. The optimum time for mating may appear to be more restricted in the ewe than in the litter-bearing sow or doe because the ewe normally has only one or two offspring with less opportunity for expression of competitive advantage of spermatozoa in the same female. The necessity for precise timing of insemination relative to ovulation for optimum fertility may account for the variability and inconsistency of results following artificial insemination timed on the basis of marks by vasectomized rams (Inskeep \& Cooke, 1968).

The observation of a $68 \%$ conception rate in ewes mated \pm 60 min of an appointed hour suggests that if techniques of artificial insemination are adequate, detection of heat is not necessary to achieve at least a $68 \%$ conception rate near the end of the breeding season. On the basis of the data presented, it is reasonable to recommend that insemination should be carried out 15 to $11 \mathrm{hr}$ before ovulation in the ewe.

In these experiments, the evidence does not permit the conclusion that the proportion of offspring from a male is the same as the proportion of eggs fertilized by that male. A differential in embryonal survival may exist, although 
the data do not suggest this. This question may be resolved by labelling each spermatozoon in a population and identifying the fertilizing spermatozoon soon after penetration.

\section{ACKNOWLEDGMENT}

The author gratefully acknowledges the generous assistance of many colleagues in the sometimes onerous details in the conduct of the experiments, especially D. Bullock, D. Dhindsa, D. Foster, W. Gibson, G. Kaltenbach, L. Keyes, G. Niswender, Z. Piasek, J. Roche and A. Tiwari.

\section{REFERENCES}

DAy, B. N. (1962) The reproduction of swine. In: Reproduction in Farm Animals. Ed. E. S. Hafez. Lea \& Febiger, Philadelphia.

Dzivk, P. J. (1965a) Timing of maturation and fertilization of the sheep egg. Anat. Rec. 153, 211.

Dziuk, P. J. (1965b) Double mating of rabbits to determine capacitation time. F. Reprod. Fert. 10, 389.

Dziuk, P. J. \& Baker, R. D. (1962) Induction and control of ovulation in swine. F. Anim. Sci. 21, 697.

Dziuk, P. J., Cook, B., Niswender, G. D., Kaltenbach, C. C. \& Doane, B. B. (1968) Inhibition and control of estrus and ovulation in ewes with a subcutaneous implant of silicone rubber impregnated with a progestogen. Am. 7. vet. Res. 29, 2415.

HARING, F. (1937) Der Einfluss des Begattungszeitpunktes währand der Rauschzeit beim Schwein auf den Befruchtungserfolg und das Geschechtsuerhältnis der Ferkel. Züchtungskunde, 12, 1.

Hunter, R. H. F. \& Dziuk, P. J. (1967) Sperm penetration of pig eggs in relation to the timing of ovulation and insemination. F. Reprod. Fert. 15, 199.

Inskeep, E. K. \& Cooke, C. E. (1968) Artificial insemination and preservation of semen. In: Proc. Symp. Physiol. Reprod. Sheep. Ed. G. E. Scott. Colorado State University, Fort Collins.

McKenzie, F. F. (1932) The optimum time to breed gilts. Bull. Mo. agric. Exp. Stn, 310, 15.

Miller, O. C., Roche, J. F. \& Dziuk, P. J. (1969) Estimation of the optimum interval between insemination and ovulation in the rabbit by double insemination. F. Reprod. Fert. 19, 545.

Niwa, T. (1961) Researches and practices in the artificial insemination of pigs. Proc. IVth Int. Congr. Anim. Reprod., The Hague, 1, 83.

Polge, G., DAy, B. N. \& Groves, T. W. (1968) Synchronisation of ovulation and artificial insemination in pigs. Vet. Rec. 83, 136.

Roche, J. F., Dziuk, P. J. \& Lodge, J. R. (1968) Competition between fresh and aged spermatozoa in fertilizing rabbit eggs. 7. Reprod. Fert. 16, 155.

Sarson, R. \& Moxley, J. E. (1966) The use of blood groups as markers in a double mating program in swine and evidence for preferential fertilization. Proc. 10th Europ. Anim. Blood Groups Conf., Paris, p. 171. Institut National de la Recherche Agronomique, Paris.

Sumption, L. J. (1961) Multiple sire mating in swine; evidence of natural selection for mating efficiency. 7. agric. Sci., Camb. 56, 31.

WiLLEMSE, A. H. (1966) The importance of oestrus behaviour for determining the right time for insemination. Veeteelt-en Zuivelber. 9, 274. 